\title{
Sino-American Tensions and Their Effects on Counter- terrorism Operations in Djibouti
}

\section{Paul Fricker}

DOI: https://doi.org/10.22151/politikon.49.5

Paul Fricker is a current Master's student at the London School of Economics specialising in conflict. His areas of research are conflicts within Africa and the Middle East. Former work includes political commentary and a submission to a student journal. Email:paulfrick@,live.co.uk.

\begin{abstract}
This research note examines the tensions between the United States and the People's Republic of China in Djibouti. Djibouti has become a battleground of interests between the US and China with both building military bases on its territory. The People's Liberation Army Navy (PLAN) utilises its base to conduct naval operations and to implement the Belt and Road Initiative (BRI), often conflicting with US operations and interests. The research note relies on primary documents to investigate the interaction between the two states over Djibouti and to assess whether and how China's presence is an obstacle to US counterterrorism operations. This analysis indicates that a conflict of interests between the US and China is inevitable, but the US' counterterrorism operation in Djibouti can be protected from the diplomatic conflict.
\end{abstract}

\section{Keywords}

Africa; China; Counter-terrorism; Djibouti; Relations; Security; United States 


\section{Introduction}

In the wake of the bombing attacks of September $11^{\text {th }}, 2001$, the US has pursued a counterterrorism operation internationally to combat security threats. The growth of groups including the Taliban, the Islamic State, al-Qaeda and al-Shabaab within the MENA region required the US to maintain a physical presence within the region and to cooperate with national counterterrorism initiative. The presence of the US military's Camp Lemonnier in Djibouti is crucial because it provides Washington with an operations' base to coordinate resources, personnel and military operations around the Gulf of Aden. Djibouti's location allows the US to cooperate with international powers through land and sea activities, antipiracy campaigns and diplomatic missions. China's investment in Djibouti has diluted the US' dominance in the state, allowing China to influence the local government and potentially disturb US operations, especially its counterterrorism missions. China's campaigns for economic expansion and diplomatic security varies from the US and their allies, damaging US operations within the MENA region.

The participation of both in the United Nations (UN) and other international fora has demonstrated cooperation in areas including counterpiracy and counterterrorism, showing that the powers can communicate to address national security issues. But resource and power competition have soured relations, as identified by statements from US diplomats including John Bolton, Robert O’Brien and Jake Sullivan. Identifying Chinese and US ambitions alongside their conflicts and conformities is crucial when discussing whether China's presence within Djibouti is detrimental to US counterterrorism operations. This research note will utilise archival material and diplomatic documents from Djibouti, China, the US alongside other states to examine the intentions of China's expansion within Djibouti and will assess the perceived risk posed by China to US counterterrorism initiatives. The research note will further investigate whether US-China tensions globally impact Djibouti and its politics.

\section{China's Expansion in Africa}

In November 2015 the Chinese government announced a ten-year lease with Djibouti over the Bab el-Mandab Strait. The rental of the land was \$20 million USD per annum (considerably less than other state's rent prices) and they planned to appoint 2,000 of a possible 10,000 personnel to the base (Cabestan 2019, 737). The base, known as the Chinese People's Liberation Army Support Base in Djibouti (PLA Base), is $0.5 \mathrm{~km}^{2}$ with a 400m runway. The base began its operations in August 2017, and by May 2018 the construction of a pier began to increase the military facility's capabilities. The announcement 
represents an early manoeuvre by China to consolidate its power in Africa with a physical presence. As Krupakar (2017) notes, "China has realized that it can ill-afford to be perennially dependent on Western powers for global security underwritings" (Krupakar 2017,208) because they don't share common ideologies and the US (alongside their allies) seeks to undermine China's presence. He further notes that the PLA base represents an incubus for the diplomatic conflict between China and the US (Krupakar 2017). The PLA base therefore represents diplomatic tensions between China and the US, with China utilising the base to secure its territorial security. This distrust of the US to maintain territorial security has frequently generated animosity and mistrust between China and the US, potentially damaging US counterterrorism objectives (Ibid, 208).

There are six official objectives of the PLA Base. These are to 1) logistically support the People's Liberation Army Navy (PLAN), 2) increase China's combat capabilities, 3) increase China's presence in the South China Sea, 4) further Chinese influence in national African politics, 5) mobilise UN affiliates to operations within the region and 6) assist humanitarian missions (Cabestan 2019, 746).

The PLA Base is an asset for the PLAN because the port supplies resources and personnel to the PLAN vessels operating around Somalia and the South China Sea. The port also accommodates the PLA supply transfer through airborne and naval channels. Between 2008-2015 China deployed over 60 warships in 21 escort missions around the Indian Ocean, with a prospective increase in operations from 2017 following the PLA Base commencing activities (Henry 2016, 17). The increase in operations, combined with further developments of ports in Africa, highlights Beijing's growing activity in the continent. China operates eleven ports in Africa and influences another 36 through funding or construction. China's ports investments in the region provide Beijing with local allies which are often encouraged to align with China's policy objectives (Deveremont 2019). This activity undermines the US presence at maritime choke points, including the Bab el-Mandab Strait.

The Indian navy monitored an increase of Chinese vessels and submarines in the Indian Ocean Region (IOR), the Malacca Straits, Gulf of Aden and the Red Sea. India criticised China for their deployment of Unmanned Underwater Vehicles (UUVs) in IOR since December 2019, which have completed 3,400 surveillance missions (Sutton 2020). Theses missions surveyed areas of material interest, indicating that China hoped to find lucrative areas to extract resources from withing the IOR. China's research missions highlight interest in the region's natural resources, furthering anxiety that China is considering expansion which, in turn, would increase China-India tensions within the IOR (Albert 2016). 
This expansion in Chinese activity and attempts to consolidate their power alarms the US and its allies; because Beijing's presence seeks to challenge their authority and counterterrorism operations, whilst the PLA base in Djibouti has allowed China to conduct a more confrontational role in the US-China tensions (Stilwell 2020). The PLA base also enables China to carry out expansion missions in areas like the IOR thus; increasing Beijing's outreach.

The PLA has completed humanitarian missions including the evacuation of nationals during the Libyan (2011) and Yemen (2015) crises (Lei. 2017, 56-57). Providing security for the approximately 100,000 Chinese nationals residing in the horn of Africa is key for China; because it allows them to form economic and political connections in the African continent. The PLA Base is important in providing Chinese nationals with support during emergencies (Cabestan 2019, 739). The UN deployed troops to the MENA region from the PLA Base and in December 2015 China increased its UN peacekeepers to 8,000, directing them to operations in states including South Sudan, Mali, and the Congo. The base legitimises China's presence in Africa while allowing international organisations to utilise Chinese assets. The UN's use of the PLA Base further secures China and reduces the intensity of US attempts to remove them from the territory. The UN does assist the US' counterterrorism operations while providing security for international powers. The PLA Base is therefore an unwelcome source of support to the US' counterterrorism operations in the MENA region. The presence of the UN also encourages communication between the US and China.

\section{Diplomatic relations}

A significant threat to the US' security and a driver of Chinese foreign policy in the MENA region is the China's Belt and Road Initiative (BRI). This originates from China's ports of Guangzhou and Fuzhou via the African ports in Kenya and Djibouti. According to the Chinese government, the BRI pursues four key policies: 1) the re-engineering of China's strategic environment, 2) the projection of Chinese economic power, 3) the security of Chinese access to energy and minerals and 4) the boosting in economic growth in western China. The BRI is expected to cost $\$ 1.4$ trillion, eleven times larger than the US Marshall Plan and is far more ambitious because it intends to expand China's relations across three continents. Chinese expansion jeopardises US' investments in mineral industries in the Gulf of Aden, potentially reducing US' supply, as China's investments in African states, larger consumption and transport links offer an alternative for mineral distributers. China's focus on establishing diplomatic and cultural relations with African states also allows them to 
undercut the US' presence there. The BRI is therefore a front for US-China tensions (Chatzky and McBride 2020).

The project aspires to connect Chinese businesses, allowing them to trade and transport commodities at a reduced rate without foreign interference. This provides the government of China with more political power and influence within the countries developing BRI (Tarrosy and Vörös 2018). Djibouti has benefited from the BRI, with installations of water pipelines and infrastructure development (République de Djibouti 2016).

The BRI is partially funded by African states including Djibouti who have benefitted from Chinese loans. The strategy has generated policies of debt-servitude. African states who fail to repay loans are obliged to offer land to China at a significantly reduced price. This undermines US influence and allows China to expand territory by offering stimulus calculated to result in debt, thus expansion. The US embassy has opposed the BRI since its inception, citing allegations of fraud, manipulation and criminality. The World Bank has also barred the BRI from construction projects as it found evidence of fraud (US Embassy in Georgia 2020).

Recent infrastructure projects funded by the Chinese government and private businesses in Djibouti, including railways, ports, pipelines, hospitals, and stadiums, have contributed to Djibouti's debt, expanding from 50\% to 104\% of GDP between 2014 and 2018. As a consequence of this, Djibouti had to offer alternative methods of payment through trading subsidies, territory, diplomatic assistance and other initiatives deemed beneficial to Beijing. Chinese diplomatic tactics seek to acquire land rights and to gain support from states that have expressly opposed the US. China's debt-servitude modus operandi does not directly confront US' counterterrorism operations, but it promotes de facto Chinese expansion while damaging recipient state's economies.

\section{US Operations within Africa}

Throughout the twentieth and twenty-first centuries the US sought to retain a presence within Africa to ensure security from competitor states and groups representing a threat to its own existence and business interests.

The strategy of supporting smaller states to combat security threats was a significant component of US foreign policy because it promoted a physical and ideological presence, allowing the US to face threats by distributing troops and conducting operations. In fact, US campaigns in Libya, Syria, Iraq and Afghanistan were designated as essential to maintaining 
Western security, but their results were inconsistent and generated condemnation from China, Russia and the wider international community.

A US policy of political domination resonates throughout its National Security Strategy, detailing the rising threat of states that conflict with US interests and jeopardise its own security. In the 2017 report The White House states that:

“America's military remains the strongest in the world. However, U.S. advantages are shrinking as rival states modernize and build up their conventional and nuclear forces. Many actors can now field a broad arsenal of advanced missiles, including variants that can reach the American homeland" (The White House 2017, 3).

The concern for US security is abundant, acknowledging the rising capabilities of enemy states including Iran, China and Russia in the Gulf of Aden and globally. Donald Trump's Presidency concluded with US-Chinese relations straining. Chinese influence has been growing steadily within Africa since 2000, with Chinese companies spending greater amounts on developing foreign relations with African nations. The Forum on Africa-China Cooperation (FOCAC) was formed in 2000, allowing Chinese initiatives to cooperate further with African states. The first conference, held in Beijing October 2000 included forty-four African nations, with China offering aid packages, interest-free loans, and business deals to African states throughout the conferences held in Beijing (Sina English 2006). The 2015 conference offered around $\$ 60$ billion in financial incentives to the African countries attending (China Daily 2015). Chinese initiatives are a concern for the US, and they have the potential to change foreign relations between the three continents.

Meanwhile, the US has economic programmes through various formats including the Free Trade Agreement (FTA) initiative. Approximately forty African countries benefit from the African Growth and Opportunity Act providing financial aid and allowing the US to enjoy a diplomatic influence over its beneficiaries as the states supporting the US in the UN; and sustaining its diplomatic presence (Carafano 2019).

At the same time, the Chinese government is also subject to less diplomatic and international scrutiny, allowing Beijing to support governments like Sudan with less international condemnation. According to John Bolton, President Trump's former Security Advisor:

"[T] his is a very important point for the U.S. and the West as a whole to wake up [to],". In Bolton's view, if the state of Djibouti leased the port to the People's Republic of China, "the balance of power in the Horn of Africa, a major artery of maritime trade between Europe, the Middle East, and South Asia would shift in favour of China" (Maru 2019). 
The US' concern over China's increasing economic and diplomatic influence has been exemplified by Beijing's action in Djibouti, demonstrating that its presence is threatening US counterterrorism operations as the US no longer has unlimited diplomatic influence in the region. Bolton's remarks on Djibouti represent the increasingly confrontational US policy against China, demonstrating the value of the base and the wider conflict it is generating.

\section{Shifting attention to counterterrorism}

The fall of the Soviet Union and the rise of terrorist attacks required the US to shift focus onto the MENA region because countries including Somalia, Iraq and Nigeria became states harbouring terrorist groups. Their lacking ability to combat terrorist groups generated a threat to Western security when factions including the Taliban and Islamic State (IS) became able to carry out attacks on the West. Failure of the local governments to fight these terrorist groups has enabled them to take advantage of the population for its own purposes. For instance, Al-Shabaab achieved a high GDP through an un-challenged influence in Somalia, allowing it to fund its campaigns from stolen property and taxing the locals (Keatinge 2014, 16-18).

The US sought to combat this security threat through targeted initiatives supporting states fighting terrorist groups. In 2007, the United States Africa Command (AFRICOM) was formed as the first US foreign policy unit with a specific focus on African security. The US assisted governments such as Somalia and Nigeria, providing training, munitions, and tactical support, allowing the states to defend themselves, establish an effective government and develop infrastructure to combat the groups and restore control. US Major-General Jeffrey Kohler stated in 2003, 'What we don't want to see in Africa is another Afghanistan, a cancer growing in the middle of nowhere' (Emerson 2008, 53). Somalia is frequently described as a 'failed state' by the international community with an inefficient infrastructure for properly combatting rebels and leaving the room for exploitation and domination by alShabaab (International Crisis Group 2008). The recent surge in US support for the state and the training of its military has resulted in al-Shabaab losing territory, as international forces have been able to combat them (Barnes 2016). AFRICOM uses bases, including in Djibouti to conduct military operations, gathering intelligence, reconnaissance and air strikes to assist Iraqi and local Syrian forces against the remnants of ISIS (Carafano 2019). The Djibouti base is critical for this operation, allowing the US to oversee and influence governments across the continent. US Army Major General Joel Tyler highlights the pivotal role of Camp Lemonier in US operations, stating that " $[\mathrm{t}]$ he training and equipment that U.S. Africa 
Command provides to the Rapid Intervention Battalion uniquely demonstrates the U.S. commitment to enhancing our shared goal of improving regional security and stability on the continent. Our partnership and training continue to be in demand" (US Embassy in Djibouti 2020).

Nathaniel Allen (2018, 664-667) suggests that AFRICOM policy either enhances the capacity of partner states to establish a coherent and secure government or generates political instability by ignoring corruption and entrenching repressive allies. Scholars remain divided on the effectiveness of the policy, with Zeleza $(2013,174)$ stating that Africans “don't trust the military as a partner in development, and fear mission creep for AFRICOM to militarization and securitization of economic relations with the US". China is a critic of AFRICOM, arguing that the US' presence within Djibouti is detrimental to counterterrorism operations because they generate further instability (Allen 2018).

The Djiboutian government itself appeared to welcome the US' presence within their state. Its foreign minister, Mahmoud Ali Youssuf stated in 2014: "Djibouti is one of the top targets of al-Shabaab in the region... If we can contain them, ok, if we can get rid of them it's better" (Gardner 2014).

\section{Military bases and their necessity for US operations}

The US has approximately thirty-four military bases in Africa. Camp Lemonnier is central for the Pentagon operations in the region, allowing Washington to station troops, drones, and aircraft in the Gulf of Aden. The base's centrality and Djibouti's stability were key drivers for the US' development in the area.

For Rear Admiral Richard Hunt, former commander of the US Combined Joint Task Force-Horn of Africa, "We feel the best way to counterterrorism is to go after the conditions that foster terrorism" (Emerson 2008, 58). US initiatives are central to the US' foreign and counterterrorism policy because they instruct Western and local militaries, allowing them to become self-sufficient in combatting terrorism.

The Combined Joint Task Force-Horn of Africa (CJTF-HOA) and AFRICOM operate from Camp Lemonnier, with further instalments in Chad, Niger, Mali, Morocco and Algeria. The East Africa Response Force (EARF)'s main headquarters is situated in the Djibouti base. EARF's operation is critical for the US, as its rapid dispatch saved US staff in the Tanzanian and Kenyan Embassies following attacks in 1998. The EARF"s deployment depends on the Djibouti base because they utilise large quantities of resources and personnel. The Djiboutian base also allows the US to launch geopolitical organisations such as the Trans-Sahara Counter-Terrorism Initiative (TSCTI) promoting US cooperation with Chad, 
Niger, Mauritania, Mali, Morocco, Algeria, Tunisia, Senegal and Nigeria to address national security issues. The US' investments of over $\$ 600$ million in financial aid have allowed local police forces and militaries to conduct research and counteract groups attempting to displace the governments (Archer \& Popovic 2007, 9-10).

In sum, the US' counterterrorism strategy depends on bases including Camp Lemonnier because they allow the US to transport personnel and resources throughout Africa. The stability of the Djibouti's government and its interaction with the allied powers ensures that the US can retain a presence there without significant challenges. The growing threat of Chinese expansion is steadily becoming an issue for US diplomats. Thus, bases including Camp Lemonnier are critical for the US' ability to influence local governance and maintain a diplomatic presence.

\section{Beijing's confrontation to the US' counterterrorism operations}

US foreign policy requires maintaining hegemony, allowing the US to influence states within Africa. The post-9/11 agenda promoted Western security through various programmes within Africa including the traditional sponsorship of pro-Western states, establishment of multi-national task forces like CJTF-HOA to train states and conduct covert operations to ensure and monitor challenges to Western ideology and US economic interests. China's expansion is motivated by security and economic expansions, often at odds with the US' initiatives. Security of the Gulf of Aden and the South China Sea is critical for both powers but involves supporting conflicting parties and agendas. The introduction of Trump's 'Indio-Pacific Strategy' increased competition whilst trade tariffs and diplomatic attacks on China highlighted a more confrontational US foreign policy from 2016, making US cooperation with China more difficult. US diplomats drafting the National Security Strategy described China "[as] determined to make economies less free and less fair, to grow their militaries, and to control information and data to repress their societies and expand their influence" (The White House 2017, 2). Chinese expansion conflicts with India and numerous US-supported powers that lobby the US to deter China from expanding. The two powers' economic interests conflict with each other as China continues to expand within Africa by building infrastructures and extracting resources. Following his inauguration, Biden highlighted the need to confront China; "We'll confront China's economic abuses; counter its aggressive, coercive action; to push back on China's attack on human rights, intellectual 
property, and global governance." (Biden 2021), suggesting that relations have not improved in recent years and the US is continuing to pursue a confrontational foreign policy. ${ }^{1}$

The state's differing ideologies generate conflict too, with the US criticising China's human rights' abuses, whilst China attacks the US for similar offences. China's strategy of territorial expansion through its debt-servitude policy and the BRI's initiatives are a common target amongst Western states. China's increasing power in the UN generates concern to the US too with Beijing pressuring African states to combat pro-Western states like Japan. The conflict between the two states is inevitable in Djibouti, diverting US attention and resources away from its counterterrorism policy; and weakening Washington's connection to allied African states.

\section{Protection of African states}

A prominent policy for all presidents following WW2 was to provide humanitarian aid to African states. Barack Obama's strategy increased communication with African states and China. However, following the election of President Trump, the US adopted a harder, more confrontational policy. The withdrawal from the Iranian nuclear deal, the increase of Chinese tariffs and the 'Deal of the Century' (a polarising US policy of declaring full support for Israel) demonstrates Trump's desire to confront China and its interests in the MENA region. Trump stated that China has sought to "advance anti-Western views and spread false information to create divisions among ourselves, our allies, and our partners", demonstrating a deep mistrust of Chinese ambitions and the inevitable exploitation of weak states (The White House 2017, 1). Jean-Pierre Cabestan $(2019$, 8) highlighted this concern with the Djiboutian base, stating that Western observers are impressed and concerned by the Chinese construction process, with underground facilities and likely ordinance installations, and they believe that the base in Djibouti is evidence of future Chinese ambitions to expand within the continent. The protection of African states from China has become a key policy for Obama, Trump and Biden. The language used by each president has become more confrontational, demonstrating the increasing conflict between the parties regardless of who is holding office.

\section{US Security}

In December 2018, former National Security Advisor John Bolton declared during an address to the Heritage Foundation that the rise of Chinese and Russian influence in Africa was an attempt to gain power over the US (The White House 2018). He and his team

\footnotetext{
1 'We'll confront China's economic abuses; counter its aggressive, coercive action; to push back on China's attack on human rights, intellectual property, and global governance" (Biden 2021).
} 
highlighted incidents including intellectual theft, aircraft attacks and ideological differences threatening the US' presence in the region. The US is concerned over China's attempts to steal its intellectual property. This is an issue for the US in Djibouti following its technology's' cloning and subsequent sale to African states as part of Chinese diplomacy/ expansion's funding efforts. Intellectual property theft also undermines US counterterrorism attempts as it loses its technological superiority over competitor states purchasing copied technology from China. The loss of income for the US is calculated at between $\$ 225-\$ 600$ billion per annum (US Embassy and Consulates in China 2020). Further to this, the US established bodies including the National Security Innovation Base (NSIB) protecting US intellectual interests. The administration stated:

"We must defend our NSIB against competitors. The NSIB is the American network of knowledge, capabilities, and people...that turns ideas into innovations, transforms discoveries into successful commercial products and companies, and protects and enhances the American way of life" (The White House 2017, 21).

Intellectual property theft alongside the loss of technological dominance allows other powers to intimidate US forces. Incidents including the laser attack, in which two US military pilots were temporarily blinded, increased tensions. The US suggested that China attempted to crash a US military aircraft and disrupt US operations on its territory. China denies the incident, but its possession of such lasers has been recorded, and their origin was believed to be from China's military base (Sonne 2018).

Joint initiatives between the two states to combat terrorism have been partially successful throughout the twenty-first century, but the programmes have been undermined by ideological conflict. China's debt-servitude approach and sponsorship of US enemies has generated international condemnation, demonstrating that China's priorities are detrimental to US counterterrorism.

The two powers dispute the designation of terrorist factions. China's counterterrorism operation focuses on internal terrorist threats whereas the US is predominantly externally orientated. Groups including Hamas have been points of contention between the US and China. Beijing also criticised Washington for supporting dictators including Saddam Hussein and its involvement in anti-government rebellions like Libya, destabilising the country. The divergence over the designation of terrorism damages the US' counterterrorism operations because China refuses to engage in campaigns that potentially threaten its economic interests, leading to an inconsistent international approach to counterterrorism. 


\section{Involvement of Third Parties}

Djibouti hosts many multinational forces by providing leases for military bases. International powers have an interest in the trading routes surrounding Djibouti and its proximity to enemy states, providing an effective and rapid response base. The variety of interest has generated tensions between states, with China conflicting frequently with Western countries, as well as with Japan and India over the territory surrounding Djibouti. The states' allegiances to the US and international organisations including NATO, the UN, and more exclusive groups conflict with Chinese interests because China's competitors have a greater combined influence over Djiboutian affairs than Beijing and its allies. China retains a $38.8 \%$ stake in the Port of Djibouti through investments and its debt-servitude approach outlined above. The investment is a concern for rival states because China's influence within the region is increasing and its attempts to appease other African states has begun to unhinge US dominance. The US has thus sought to cooperate with third parties to counter China's domination.

The French government also expresses concern for China's activity within Africa. Paris despatched two Mirage planes to monitor Chinese activity daily following their initial establishment of the Diboutian base in 2016/17. The French are concerned that their influence could be undermined by China through the BRI and its debt-servitude policies that offer an alternative to French diplomacy or take territorial control of former French-allied territory. Chinese diplomatic relations with the Djiboutian government have escalated over recent years through relief packages and infrastructure development projects seeking to appease the Djiboutian government (Irish 2019). France currently stations troops In Djibouti and frequently conducts military training operations. These improve diplomatic relations between the powers and highlight French military strength (Ministère Des Armées 2020).

Japan and India hold further security concerns for the PLA Base. During August 2017, the Japanese air force spied on China's warships moored at the PLA Base, indicating that China's presence could jeopardise Tokyo's security in the South China Sea. Japan has created bases within Africa to combat China and other security threats (Pajon, 2017, 9, 25). Japan and India cooperated to combat China's BRI expansion plans in the MENA region because they believed that the BRI undermined Japanese and Indian security through the construction of trading routes and pipelines located near their territories. From 2011 Japan stationed 150 military personnel on Djiboutian territory to monitor construction points. The corruption of African governments has been utilised by China to undermine fair competition on the international market by offering cheaper and larger contracts compared to Japan's 
allies (Gouriellec 2010, 1). States in the West and Asia formed committees including the Indian Ocean Naval Symposium (IONS) and the Indian Ocean Rim Association (IORA) to foster regional maritime cooperation and ensure collective security against China and Russia (Krupakar 2017, 215-217). The involvement of allied states is advantageous to US counterterrorism as the combination of US, Indian and Japanese power can obstruct to Chinese influence. Support for US counterterrorism operations within the UN and other international organisations is vital for Washington to ensure that it can remain dominant within Africa.

The involvement of third parties escalates the tensions between the US and China within Djibouti. The complex international conflicts and proxy wars conducted in the MENA region jeopardise the US' counterterrorism programme as it relies on communication with allies and rivals including China. The complex web of interests impedes communication, hindering the necessary intelligence for US counterterrorism operations. At the same time French, Japanese and other allies of the US based in Djibouti provide support for US programmes and; intelligence sharing while obstructing China's influence.

\section{Cooperation between the two powers}

Despite disputes, the threat of terrorism in Africa is substantial enough for the US and China to cooperate whilst their security is jeopardised. Cooperation through initiatives, training operations and anti-piracy activities dilute the tensions as they provide a mutual benefit. The US' national security interests reflect China's, focusing on international operations in Africa and Asia to combat terrorism through protecting established states by offering diplomatic, military and economic support. US support allows foreign states including Somalia, Sudan, Angola, and Djibouti to combat terrorism through national militaries, police and state structures. This shared interest in seeking common protection from international terrorist groups improves cooperation between states, thus protecting US counterterrorism operations. China has expressed willingness to cooperate, taking part in UN, US and international counterterrorism operations.

\section{China's Cooperation with the International Community}

China's engagement with the international community through the UN and the EU has increased. This engagement is motived by a desire to improve security for Chinese investments in Africa as well as its diplomatic relations, allowing Beijing to expand operations, including the BRI in Africa and neighbouring continents. The PLA base allows China to cooperate with locals and promotes regional cooperation, encouraging China and 
the US to combat terrorism and security threats. While China's cooperation with the international community has considerably risen, the US has criticized its action in the UN.

During October 2018 China hosted the European Union's Operation Atalanta, an EU Defence operation seeking to monitor Somalia's coastline. This joint initiative led by the EU offered training exercises with its multinational force. The PLAN conducted its first medical evacuation by helicopter from an Italian ship to the PLA base in Djibouti. The exercise was completed alongside the EU NAVFOR (Naval Force), demonstrating the PLA's close cooperation with EU activities. China, India, and Japan supported Operation Atalanta by protecting World Food Programme's (WFP) vessels. China is interested in the operation because it's located close to the South China Sea, allowing Beijing to retain a nonconfrontational presence. China is also concerned about monitoring European activity within the area and Europe's cooperation with Japan which could undermine China's territorial interests. The European presence in the Gulf of Aden is preferable to an Indian presence because they are less confrontational, therefore supporting the relatively neutral operation is an effective diplomatic incentive (European Union External Action 2019). China also encourages Djibouti's cooperation with local states, including the support for Djibouti to host the $38^{\text {th }}$ Intergovernmental Authority for Development (IGAD) summit. The summit allowed Djibouti to further its connection with its neighbours and to address regional security (République de Djibouti 2020).

China is a member of the UN Counter-Terrorism Committee (UNCTC), which was established following Resolution 1373. It is also a member of the Association of Southeast Asian Nations (ASEAN), the Asean Regional Forum (ARF), Asia-Pacific Economic Cooperation (APEC) and the Shanghai Cooperation Organization (SCO). China's membership with multiple international organisations is commendable because these associations seek to provide a platform for communication and for the establishment of a counter-isolationist diplomatic policy. The United Nations Centre on Transnational Corporations (UNCTC) demonstrates China's cooperation with the international community as it regularly attends conferences and invests in initiatives to foster communication (UNSC, 2016). Meanwhile, the financial incentives offered by China has made the country popular amongst their beneficiaries. Its ongoing engagement in the ASEAN framework provides the members with a stage for debate and for deciding key resolutions in counterterrorism initiatives. China's cooperation with Japan is beneficial by ensuring security for both countries, despite their mistrust (Tanner \& Bellacqua 2016, 97). 
China's involvement in the international community is beneficial to US counterterrorism as China is seeking to cooperate with counterterrorism initiatives around Africa. This cooperation secures the US' presence in the continent and allows Washington to exert diplomatic pressure on China through various of organisations.

\section{Cooperation between China and the US}

Following the 9/11 attacks, the US focused on terrorism as the greatest international threat to its homeland. The US sought to extend diplomatic relations with China internationally despite ideological differences. China's strength and expanding affluence presented an imminent threat to US counterterrorism operations. Cooperation with China is essential to ensure efficient US operations in Djibouti without a significant impediment.

The US aspired to improve relations with China in the aftermath of the 9/11 attacks. The formation of the US-China Counterterrorism Working group provided a programme for both states to discuss counter-terrorism progress, share research and consider solutions amongst additional objectives. The group demonstrates a common interest of counterterrorism within Africa, allowing communication to be retained. The US and China approved the establishments of an FBI legal attaché and a US Coast Guard Liaison Office (set up in 2004 and 2006 respectively) located in Beijing. This was US diplomacy in China, allowing for effective mediation and a physical US presence in the capital. In 2006, China signed a Memorandum of Understanding, allowing US federal air marshals to travel to China and Chinese air marshals to travel to the US. This cooperation allows the transportation of important military personnel whenever required, assisting counterterrorism operations during national crises and in Africa. Trade and economic cooperation against terrorism has been occurring through treaties and agreements between the US and China. The Container Security Initiative (CSI) is a US-introduced measure designed to mitigate terrorist threats to US soil and to maritime trade by providing security measures to US cargo. The CSI ensures security for the US through the inspection of container cargo at major ports globally, especially within China, the Gulf of Aden, and the MENA region. Cargo is inspected by foreign ports for illegal substances and terrorist material, preventing the distribution of cargo to US soil before inspection. US inspections within China demonstrates continued communication and cooperation.

In 2004, the People's Bank of China established a financial intelligence unit and began working with its US counterparts to build capacity and exchange expertise, leading to the creation of an anti-money laundering law in 2006. The Chinese government also joined the Eurasia Group on Money Laundering and Terrorist Financing, the Asia-Pacific Group 
on Money Laundering, and the Financial Action Task Force. These initiatives seek to combat international terrorist financing by identifying companies attempting to trade with terrorist groups, while preventing transactions. China's cooperation with international counterterrorism programmes is a positive sign for US counterterrorism, as it demonstrates that China has made significant attempts to interact with the global community to combat terrorism and to boost the PLA base as a communications hub. Targeting terrorism financing is vital to the US' counterterrorism programme. Conversely, Beijing's refusal to comply with these initiatives would be a diplomatic and financial disaster for the Chinese government. Rather, its membership in international organisations along with the US and other partners demonstrates China's desire to cooperate globally and ensure security of its African interests, including the PLA Base (Tanner and Bellacqua 2016, 81).

\section{Conclusion}

Following 9/11, conduction international counterterrorism operations has become a foreign policy priority for the US. Djibouti is a critical base for the US, allowing the US to operate naval, military, and diplomatic missions in the Middle East and North Africa. Therefore, guaranteeing security for this base and the surrounding region, while combatting terrorist groups is of paramount importance to Washington.

US counterterrorism requires communication between states because intelligence is critical for operations against subversive terrorist groups. The People's Republic of China has impeded US counterterrorism operations as Beijing seeks to pursue its economic and diplomatic missions often conflicting with those of the US. These operations are also in disagreement with Japan, France, and India because they are centred on a debt-servitude approach with the BRI seeking to undermine competitors' presence in Africa. The animosities between China and India in the South China Sea generate conflicts between Beijing and US allies. Moreover, China's economic investments, support for powerful states and its increasing influence internationally allow the country to challenge the previously unimpeded US presence in Africa. Even though, China and the US have signed agreements, treaties, and carried out common operations, but the increasing aspirations of China, the rise of a Russian threats and the changing nature of terrorism have strained communications between the two. US counterterrorism operations in Djibouti will remain as long as the terrorist threat from groups including the Islamic State, al-Shabaab and Boko Haram threatens the US and local security. The combined action of the US and its allies is countering China's influence in Djibouti, but China's increased presence internationally makes the longterm operation of US counterterrorism activities in the MENA region uncertain. 


\section{References $^{2}$}

Albert, Eleanor. 2016. "Competition in the Indian Ocean." Council on Foreign Relations. https://www.cfr.org/backgrounder/competition-indian-ocean.

Allen, Nathaniel. 2018. “Assessing a Decade of U.S. Military Strategy in Africa.” Orbis 62 (4): 655-669. https://doi.org/10.1016/j.orbis.2018.08.011.

Archer, Tony and Tihomir Popovic. 2007. "The Trans-Saharan counter-terrorism initiative: The US war on terrorism in North Africa." The Finnish Institute of International Affairs. https://www.files.ethz.ch/isn/32043/16 TransSaharanCounter'Terrorism.pdf.

Barnes, Cedric. 2016. "Somalia's Al-Shabaab down but far from out.” International Crisis Group. https://www.crisisgroup.org/africa/horn-africa/somalia/somalia-s-alshabaab-down-far-out.

Bellacqua, James and Tanner, Scott. 2016. "China's Response to Terrorism”. U.S.China Economic and Security Review Commission. https://www.uscc.gov/research/chinas-response-terrorism.

Biden, Joseph. 2021. "Remarks by President Biden on America's Place in the World". The White House. https://www.whitehouse.gov/briefing-room/speechesremarks/2021/02/04/remarks-by-president-biden-on-americas-place-in-the-world/.

Carafano, James, et al. 2019. "Preparing the US National Security Strategy for 2020 and Beyond." The Heritage Foundation. https://www.heritage.org/defense/report/preparingthe-us-national-security-strategy-2020-and-beyond.

Cabestan, Jean-Pierre. 2019. "China's Military Base in Djibouti: A Microcosm of China's Growing Competition with the United States and New Bipolarity." Journal of Contemporary China 29 (125): 731-747. https://doi.org/10.1080/10670564.2019.1704994.

Chatzky, Andrew and McBride, James. 2020. "China's Massive Belt and Road Initiative." Council on Foreign Relations. https://www.cfr.org/backgrounder/chinas-massivebelt-and-road-initiative.

China Daily. 2015. "Xi announces 10 major programs to boost China-Africa cooperation in coming 3 years." https://www.chinadaily.com.cn/world/XiattendsParisclimateconference/201512/04/content 22631225.htm.

Deveremont, Judd. 2019. "Assessing the Risks of Chinese investments in SubSaharan African Ports.” Centre for Strategic and International Studies.

\footnotetext{
${ }^{2}$ All online sources were accessible as to 25 June 2021.
} 
https://www.csis.org/analysis/assessing-risks-chinese-investments-sub-saharan-africanports.

Emerson, Stephen A. 2008. "The battle for Africa's hearts and minds." World Policy Journal 25 (4): 53-62. https://doi.org/10.1162/wopj.2009.25.4.53.

European Union External Action. 2019. "Welcoming Returning Support from French Multi-role Frigate 'La FS Surcouf.” https://eunavfor.eu/welcoming-returningsupport-from-french-multi-role-frigate-la-fs-surcouf/.

Feng, Emily and David Pilling. 2019. "The other side of the Chinese investment in Africa." The Financial Times. https://www.ft.com/content/9f5736d8-14e1-11e9-a5814ff78404524e.

Gardner, Frank. 2014. "US military steps up operations in the Horn of Africa." BBC News. https://www.bbc.co.uk/news/world-africa-26078149.

Gouriellec, Sonia. 2010. "Base militaire à Djibouti: le paradoxe de la puissance japonaise."

Academia. https://www.academia.edu/11877663/Base militaire \%C3\%A0 Djibouti le paradoxe d e la puissance japonaise.

Henry, Jérôme. 2016. "China's Military Deployments in the Gulf of Aden: AntiPiracy and Beyond." Asie Visions, 89, Ifri. https://www.ifri.org/sites/default/files/atoms/files/chinas military deployments in the gulf of aden anti-piracy and beyond 0 .pdf.

International Crisis Group. 2008. "Somalia: To Move Beyond the Failed State." International Crisis Group. $\quad$ https://www.crisisgroup.org/africa/hornafrica/somalia/somalia-move-beyond-failed-state.

Irish, John. 2019. "Macron Warns of Chinese Risk to African Sovereignty.” Reuters. https://www.reuters.com/article/us-djibouti-france/macron-warns-of-chinese-risk-toafrican-sovereignty-idUSKBN1QS2QP.

Krupakar, Jayanna. 2017. "China’s Naval Base(s) in the Indian Ocean-Signs of a Maritime Grand Strategy?” Strategic Analysis. $41 \quad$ (3): 207-222. https://doi.org/10.1080/09700161.2017.1296622.

Keatinge, Tom. 2014. “The Role of Finance in Defeating Al-Shabaab.” Royal United Services Institute. https://www.yumpu.com/en/document/view/54726126/the-role-offinance-in-defeating-al-shabaab/5. 
Lei, Wang 2017. "Jibuji: keyi chengwei ZhongMei junshi hezuo de xinchuangkou" ['Djibouti can become a new window of military cooperation between China and the United States'], Shijie Zhishi (World Affairs) 16 (1): 56-57.

Maru, Mehari Taddele. 2019. "A New Cold War in Africa." Al Jezeera. https://www.aljazeera.com/indepth/opinion/cold-war-africa-190630102044847.html.

Ministère Des Armées. 2020. "FFDj : La Base navale de Djibouti, point d'appui stratégique dans l'océan Indien." https://www.defense.gouv.fr/operations/forces-depresence/djibouti/actualites/ffdj-la-base-navale-de-djibouti-point-d-appui-strategiquedans-l-ocean-indien.

Ministry of Foreign Affairs of the People's Republic of China. 2020. "Foreign Ministry Spokesperson Announces Sanctions on Pompeo and Others." https://www.fmprc.gov.cn/mfa eng/xwfw 665399/s2510 665401/2535 665405/t18475 54.shtml.

Pajon, Céline. 2017. “Japan's Security Policy in Africa: The Dawn of a Strategic Approach?" Ifri Center for Asian Studies. https://www.ifri.org/sites/default/files/atoms/files/pajon japan security policy africa 2 017.pdf.

République de Djibouti. 2016. "L'portant ratification de l'Accord de prêt signé entre la République de Djibouti et la Banque Export-import de la République Populaire de Chine.” https://www.presidence.dj/texte.php?ID=147\&ID2=2016-0607\&ID3=Loi\&ID4=11\&ID5=2016-06-15\&ID6=n.

République de Djibouti. 2020. "Djibouti abrite un sommet extraordinaire de l'IGAD.” https://diplomatie.gouv.dj/Articles/DetailArticles/460.

Sina English. 2006. The $1^{\text {st }}$ Ministerial Conference. http://english.sina.com/p/1/2006/1026/92709.html.

Sonne, Paul. 2018. "U.S. accuses China of directing blinding lasers at American military aircraft in Djibouti." The Washington Post. https://www.washingtonpost.com/news/checkpoint/wp/2018/05/03/u-s-accuses-chinaof-directing-blinding-lasers-at-american-military-aircraft-in-djibouti/.

Stilwell, David. 2020. "The South China Sea, Southeast Asia's Patrimony, and Everybody's Own Backyard." US Embassy and Consulates in China. https:// china.usembassychina.org.cn/the-south-china-sea-southeast-asias-patrimony-and-everybodys-ownbackyard/. 
Sutton, HI. 2020. “China Deployed 12 Underwater Drones In Indian Ocean”. Forbes. https://www.forbes.com/sites/hisutton/2020/03/22/china-deployed-underwater-dronesin-indian-ocean $/$ sh $=32 \mathrm{e} 6 \mathrm{f} 4 \mathrm{~cd} 6693$.

Tarrosy, Istvan and Zoltan Vörös. 2018. "China and Ethiopia, Part 2: The Addis Ababa-Djibouti Railway." The Diplomat. https://thediplomat.com/2018/02/china-andethiopia-part-2-the-addis-ababa-djibouti-railway/.

UNSC Counter-Terrorism Committee. 2016. "Press Kit 2016." Counter-Terrorism Committee Executive Directorate. https://www.un.org/securitycouncil/ctc/content/presskits.

US Department of State. 2019. "Country Reports on Terrorism 2019." https://www.state.gov/reports/country-reports-on-terrorism-2019/.

US Embassy and Consulates in China. 2020. "Secretary Michael R. Pompeo And British Foreign Secretary Dominic Raab At a Press Availability.” https://china.usembassychina.org.cn/secretary-pompeo-and-british-foreign-secretary-raab-at-a-press-availability/.

US Embassy in Djibouti. 2020. "ARICOM's New Director of Operations Visits Africa to Engage with Partners." https://dj.usembassy.gov/aricoms-new-director-ofoperations-visits-africa-to-engage-with-partners/.

US Embassy in Georgia. 2020. "China's Construction Companies Sow Chaos Worldwide." $\quad$ https://ge.usembassy.gov/chinas-construction-companies-sow-chaosworldwide/.

The White House. 2017. "National Security Strategy of the United States of America." https://trumpwhitehouse.archives.gov/wp-content/uploads/2017/12/NSSFinal-12-18-2017-0905.pdf.

The White House. 2018. "Remarks by National Security Advisor Ambassador John R. Bolton on the Trump Administration's New Africa Strategy." https://sn.usembassy.gov/the-trump-administrations-new-africa-strategy-remarks-bynational-security-advisor-ambassador-john-r-bolton/.

The White House. 2011. "US National Strategy for Counterterrorism." https://obamawhitehouse.archives.gov/sites/default/files/counterterrorism strategy.pdf.

Zeleza, Paul Tiyambe. 2013. “Obama's Africa Policy: The Limits of Symbolic Power.” Africa Studies Review 56 (2): 165-178. https://doi.org/10.1017/asr.2013.48. 